\title{
The Role of Customer Engagement and Relationship Quality toward E-Customer Loyalty in the Jordanian Online Environment
}

\author{
Sana'a Nawaf Al-Nsour ${ }^{1}$ \\ ${ }^{1}$ School of Management, , The World Islamic Sciences and Education University (WISE), Amman, Jordan \\ Correspondence: Sana'a Nawaf Al-Nsour, School of Management, The World Islamic Sciences and Education \\ University (WISE), P.O. Box 1101, 11947 ,Amman, Jordan. E-mail: snsour@hotmail.com
}

Received: November 24, 2019

Accepted: December30, 2019

Online Published: January 27, 2020

doi:10.5539/ijbm.v15n2p149

URL: https://doi.org/10.5539/ijbm.v15n2p149

\begin{abstract}
The digital world now is more dominant, and the customer shifts to online engagement and online practices. This paper aimed to develop a new framework to illustrate the impact of electronic customer engagement on relationship quality and e- customer loyalty in the online environment in Jordan. This study through reviewing the literature, extracted three dimensions of customer engagement; cognitive, affective and normative engagement. In addition to relationship quality and its mediating impact on customer loyalty.460 questioners were distributed to university student who confirmed following or liking at least one brand community on Facebook, (PLS-SEM)was used to analyze the data collected and the result showed that there is a significant impact of e-customer engagement on relationship quality and customer loyalty.in addition, relationship quality had partial mediation relation between customer engagement and e-customer loyalty.
\end{abstract}

Keywords: customer engagement, relationship quality, e-customer loyalty

\section{Introduction}

One of the building blocks of business success is the customers; therefore, building an excellent relationship with customers and achieving their loyalty remain basic strategy to success. For that reason, understanding customer engagement and relationship quality, preserving and focusing on customer loyalty in addition to interacting with the customers to institute a strong relationship, are some of the essential issues for businesses to maintain competitive advantage (Nammir et al., 2012).

Business organisations expect to gain advantage from using social media, and from online engagement with its current and expected customers, through building relationships with customers within the online environment (Pongpaew et al., 2017). Moreover, Customer loyalty is accepted as one of the best measures of success in any organisation. Marketers saw customer loyalty as vital because of its positive results on long-term success and profitability (Husnain \& Akhtar 2015). Thus, the development, maintenance, and promotion of customer loyalty remain central to the majority of corporate marketing activities (Dick and Basu, 1994).

From the need for further research to consider the relationship quality relationships with customer engagement ( Nammir et al., 2012) and it's mediation role to reach e-customer loyalty. Also, from the lack of quantitative study in this area especially in the Middle East. And the recommendations of the (American Marketing Association, 2013) to do further research to clarify customer engagement concept, particularly in social media settings, this research came to cover this gap and to incorporate studies examining customer engagement in the online environment quantitatively to lead to more generalisable findings.

This research aims to provide insight into customer engagement through the online environment. The objectives of this study are to determine the major customer engagement really matters in relationship quality and e-customer loyalty. Does the relationship quality mediate the relationship between customer engagement and e-customer loyalty?

\section{Literature Review}

\subsection{Customer Engagement}

Customer engagement gained a lot of attention from marketing researchers recently, as it's considered an important vital topic in the marketing strategy field (Puriwat \& Tripopsakul, 2014). Besides, the improvement of 
customer engagement will lead to an improvement in organisations performance, by affecting both positive word-of-mouth, and involvement with new customers. Meanwhile, there is clear evidence that improving customer engagement is related to good marketing outcomes, such as customer satisfaction and loyalty (Kumar et al., 2010).

Customer engagement can be defined as the intensity of customer participation with the organisation and with other customers, collaboratively to exchange knowledge (Wagner \& Majchrzak, 2006). Besides, customer engagement is defined as the interacting and participating of customers with the brand and its content posted on social media by becoming a co-creators (Guo, Zhang, \& Wang, 2016). Additionally, Hollebeek (2011a, p. 790), defines customer engagement as a specific cognitive, emotional and behavioural activities, that well characterise direct brand interaction. As well, Patterson et al. (2006) stated that customer engagement is the level of a customer's incidence (physical, emotional and cognitive) in their relationship with the service provider.

Mollen \& Wilson (2010) suggested that online brand engagement is a psychological process including cognitive, emotional, and behavioural presence, leading to customer loyalty for service customers. Moreover, it is the mechanism used to keep repeat purchase of brand service. Further, Bowden $(2009$, p. 65) defines participation in: "The psychological process that underpins your business and your clients. As well, Van Dorn et al. (2010) Define customer engagement as a distinct customer experience. These authors assume five dimensions of customer engagement behaviours, inclusive of:

1. Parity: positive or negative behavioural manifestations.

2. Model or method refers to the different ways in which this can be expressed by customers (for example, types of resources such as time for money).

3. Scope: Time (currently or continuous) and geographic (local or global).

4 - The nature of its impact: perception in terms of the speed of impact, and the severity of the impact, and the breadth of impact, and the longevity of the impact.

5. Customer Objectives: This embodies the customer's goal to participate

Tsai and Pai (2014) also focused on newcomers and examining the factors associated with participation in online communities. First, they use the term "community participation" in their conceptual framework and define it as "proactive behaviour of participation", which includes: dissemination, uploading and promoting participation. Evaluate sharing behaviour using objective behavioural data. Second, they use multi-element measures of the participation structure that have been considered first-class.

Consumer engagement is interactive, and therefore this engagement can only appear if there is a relationship partner to interact with and use it as a reference for engaging, Dessart, Laurence (2015). Ray et al. (2014) developed a conceptual model to explore the relationship between customer engagement with other relevant structures, and they designed an experimental study to assess the validity of the proposed model. "Community participation": a term that has been used by the authors. Which is conceived as "a positive psychological state in which online community members are interested about pro-community tasks that benefit other members of the online community as a whole" (Ray et al., 2014: 529).

Chandler and Lusch (2015) argue that correlation occurs when the five characteristics are aligned (i.e., correlation is the alignment of past, present and future actions, as well as temporal and relational correlation). Bagozzi, Dholakia (2002) and Dholakia et al. (2004) investigated the concept of participation in online communities for the first time. This new interactive environment has been empowered by modern technological innovations and significant investment by organisations in the development of online brand communities. Baldos et al. (2015) addresses in particular and accurately the current gap regarding the need for more studies to develop a range of customer engagement in online brand communities. Although they try to bridge the gap primarily by examining customer motivations in online brand communities, they also suggest these dimensions as different dimensions to build "customer engagement".

Vivek et al. (2012) made a complement to the cognitive, emotional and behavioural triad by adding a social dimension to the equation. At the same time (Hollebeek \& Chen 2014; Hollebeek, Glynn, Brodie 2014; Hollebeek, Srivastava and Chen 2016). It depicts participation as a multidimensional structure with an emotional and behavioural dimension, a view espoused by several other participatory studies (e.g. Mollen and Wilson, 2010; Wirtz et al., 2013). Rissanen and Luoma-Aho (2016) explains that participating positive customers have been shown to lead to better brand perceptions and brand reputation. Other positive outcomes of customer engagement are loyalty, empowerment, emotional connectedness and brand communication (Rissanen \& Luoma-Aho, 2016). Customer engagement can lead to buying intentions and decisions that create opportunities 
to increase sales and profitability (Barger et al., 2016). The negative correlation is associated with failed expectations, personal values and emotions (Rissanen \& Luoma-Aho, 2016).

\subsection{E-Customer Loyalty}

Because the cost of attracting new customers is much higher than the cost of retaining old customers, maintaining customer loyalty is a major problem for service companies Liu et al. (2011). In the online environment, loyalty is changed to e- loyalty, and it is defined as "a customer's favourable attitude toward the e-retailer that results in repeat buying behaviour" (Srinivasan et al., 2002). Further, Hur et al. (2011) stated that e- customer loyalty is the customer's intention to visit the website another time with or without online transactions. Kotler and Keller (2016) detailed that consumers can benefit by loyal within their online Repeat Purchase (e-customer loyal to product purchases), or their retention as the resistance to negative inspirations about the company. Existing literature is full of evidence that trust and commitment affect customer loyalty. For example, research shows that when customers consistently receive a competent service, their confidence levels increase, leading to long-term relationships with the company (Balaji, 2015).

\subsection{Relationship Quality}

The main objective of relationship marketing theory is to identify the main drivers that influence the company's important outcomes and better understand the causal relationships between its drivers and results (Thurau et al, 2002). Furthermore, Strong and poor quality relationship has an impact on the attitude adopted by customers. If the quality of good relationships may reduce uncertainty and have an impact on the expectation of future permanent interaction (Crosby, Evans and cowls, 1990), as well as Crosby et al. (1990) indicated that the quality of the relationship has a pronounced effect on the expectation of future interaction in The article "Relationship quality in services that sell perspective of personal influence". Moreover, Ray et al. (1994); Bejou et al. (1996) agreed that the quality of the relationship consists of at least two dimensions; the dimensions of trust and satisfaction. Moreover, Steenkamp (1995) argues that the quality of the relationship between companies reflects that trust; Commitment and conflict always expect and invest as you like.

Brodie (2003) stated that to maintain the quality of the relationship between service providers, their relationship must include trust, satisfaction and emotional commitment. As well, Hennig-Thurau et al. 2002 stated that the main challenge for researchers is to identify and understand how administratively controlled case variables affect important outcomes of relationship marketing (e.g. customer loyalty and oral communication). Customer trust in this study is considered as a componant of relationship quality factor. The trust exists if the customer believes that the service provider is reliable and has a high degree of integrity as stated (Murman, Zaltman, Deshpande 1992; Morgan and Hunt 1994)

Hennig et al. (2002) Describe that the benefits of a relationship are directly and positively correlated with the level of commitment a customer may encounter with a service provider. In most service companies, customers pay before getting the service. That's why open communication is vital and reduces problems and positively increases customer expectations. Therefore, this research suggests that strong engagement with customers is very important for a long-term relationship.

Customer satisfaction is considered as a component of relationship quality factor in this study. Fornell, 1992 suggests that customer satisfaction is a comprehensive assessment of customers towards a complete buying experience on products and services. Customer satisfaction can be considered a measure of the quality of the relationship between the customer and the company (De Wulf and Odekerken-Schro"der, 2001). Satisfaction considered as the result of post-purchase customer assessment of tangible and intangible brand features and the main determinant of customer loyalty (Krystallis \& Chrysochou, 2014). Customer satisfaction plays an important role in the success of business strategies (Gil \& Cervera, 2008). Customer satisfaction helps organisations and businesses increase their revenue and achieve competitive advantage (Lewin, 2009).

\subsection{Customer Engagement and Relationship Quality, Customer Engagement and Customer Loyalty}

Customer engagement is considered to be associated with several brand relationship outcomes directly and positively, such as satisfaction, trust, emotional and loyalty (Brodie et al., 2013). The role of mediation of trust and commitment in stimulating loyalty from participation appears to be generally supported (Hollebeek, 2011a). Further, Nammir et al. (2012) stated that customer Engagement levels lead to higher levels of relationship quality. The consequences of the proposed customer engagement are, for example, trust, satisfaction, and loyalty (Brodie et al., 2013; van Doorn et al., 2010).

Marzocchi et al. (2013) also support this assertion, demonstrating the loyalty of positions (a Synonym for brand commitment and brand confidence lead to increased behavioural levels. Wafaa.Gummerus et al.( 2012) stated 
that customers are becoming more satisfied and loyal, and they also experience relationships that benefit from communication with the brand community. This assumption is based on the logic that clients, by engaging in different behaviours, receive the benefits of a different relationship.

\section{Research Methodology}

A quantitative method has been used in this study, through questionnaire survey in a Jordanian university, questionnaire was distributed to 1000 students, using Facebook group by sending google form survey to the university Facebook group, 660 questionnaires were returned. 460 completed questionnaire was giving back filled completely and suitable for analysis and with the condition that the respondents liked and followed at least one brand community on Facebook and therefore 460 is the actual sample size used for analysis, according to Fabrigar, Porter, and Norris (2010) and Bagozzi and Yi (2012) The sample size considered acceptable in the literature for structural equation models; therefore the sample size considered appropriate.

Choosing this sample in this study came for several reasons; new generation and especially students are more familiar to the online environment (Islam \&Rahman,2017). Moreover, Facebook is a suitable for the student as it is one of the most widely used social networking sites (Roblyer et al., 2010) and Facebook serves as an essential platform for new firms to establish brand pages for creating and preserving the relationship with customers (Islam and Rahman, 2016). University students form the highest community members active on Facebook (Burbary, 2011), and they participate remarkably in online brand communities (Islam and Rahman, 2016).

A quantitative method has been used in this research paper, notably through the application of a survey approach to gathering data. The researcher selected a questionnaire method to gather the data related to the proposed model.

\subsection{Measures}

The research constructs were developed by measurement scales adopted from previous studies. The scale was modified to fit the purpose of this study; constructs were measured by using five-point Likert scales 1 for strongly disagree to 5 strongly agree.

The questionnaire consisted of three main dimensions of this study:

Customer engagement: online customer engagement presented by (cognitive, emotional, behavioural) engagements factors using 12 items .this measure is considered accepted by (Hollebeek et al., (2014), (So et al., 2016 a) and with (Kosiba et al., 2018), who used it as measure for customer engagement in the same approach.

Relationship quality: relationship quality presented by (trust and satisfaction). Relationship quality factors were measured by 3 items. This measure is considered accepted by (Hennig-Thurau et al., 2002) and (So et al., 2016b) who used it as a measure for relationship quality in a related approach.

E- Customer loyalty: e-customer loyalty was measured using 4 items, commonly accepted measures in line with (Kosiba et al., 2018) and ( So et al., 2016a), who used to measure loyalty in a related approach.

\subsection{Study Hypothesis and Model}

Based on the literature review mentioned research hypothesis can be formulated as follow:

First: the study argues the direct influence of customer engagements factors on e- customer loyalty. Therefore, $\mathrm{H} 1$ is divided into three sub-hypotheses, like the following.

H1.1: There is an influence of emotional engagement at a significant level $(\alpha \leq 0.05)$ on the e-customer loyalty in Jordanian online environment.

H1.2: There is an influence of cognitive 1 engagement at a significant level $(\alpha \leq 0.05)$ on the e-customer loyalty in Jordanian online environment.

H1.3: There is an influence of behavioural engagement at a significant level $(\alpha \leq 0.05)$ on the e-customer loyalty In Jordanian online environment.

Second: the study argues the direct influences of customer engagements factors on relationship quality. Therefore, $\mathrm{H} 2$ is divided into three sub-hypotheses, like the following.

$\mathrm{H} 2.1$ : There is an influence of emotional engagement at a significant level $(\alpha \leq 0.05)$ on the relationship quality in Jordanian online environment.

$\mathrm{H}$ 2.2: There is an influence of cognitive engagement at a significant level $(\alpha \leq 0.05)$ on the relationship quality in Jordanian online environment. 
$\mathrm{H} 2.3$ : There is an influence of behavioural engagement at a significant level $(\alpha \leq 0.05)$ on the relationship quality in Jordanian online environment.

Third: the study argues the direct influences of relationship quality on e- customer loyalty, within a single hypothesis, like the following:

H3: There is an influence of relationship quality at a significant level $(\alpha \leq 0.05)$ on the e-customer loyalty in Jordanian online environment.

Fourth: the study argues the indirect influences between customer engagements factors mediated through relationship quality on customer loyalty. Therefore, H3 is divided into three sub-hypotheses, like the following.

H4.1: The relationship quality has mediated the relation of emotional engagement and e- customer loyalty in Jordanian online environment $(\alpha \leq 0.05)$.

H4.2: The relationship quality has mediated the relation of cognitive engagement and e- customer loyalty in Jordanian online environment $(\alpha \leq 0.05)$.

H4.3: The relationship quality has mediated the relation of behavioural engagement and e- customer loyalty in Jordanian online environment $(\alpha \leq 0.05)$.

These relationships are represented in the following model:

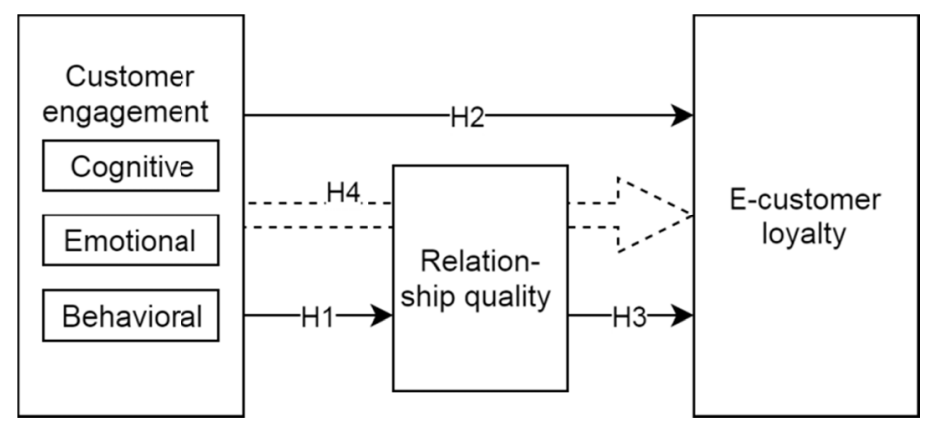

Figure 1. Study model

\subsection{Study Population}

Population of the study consists of Jordanian university students who actually liked and (or) followed at least one brand community on Facebook, by sending an online questionnaire to 1000 students in a facebook group, 660 questionnaires were returned and 460 of them were suitable for analysis and fulfil the condition of liking and (or) following at least one brand community on Facebook by the respondent. Therefore, the total sample size is 460 online engaged respondents. Table 1 shows the characteristics of the study sample.

Table 1. Study population

\begin{tabular}{|c|c|c|c|}
\hline Variable & & $\%$ & Frequency \\
\hline \multirow[t]{2}{*}{ Gender } & female & $65 \%$ & 299 \\
\hline & Male & $35 \%$ & 161 \\
\hline \multirow[t]{4}{*}{ Age } & $18-20$ & $32.8 \%$ & 210 \\
\hline & $21-23$ & $50.8 \%$ & 325 \\
\hline & $24-26$ & $14.06 \%$ & 90 \\
\hline & 27 and above & $2.34 \%$ & 15 \\
\hline
\end{tabular}

Females present $(65 \%)$ of the population; on the other hand, Males respondent are $(35 \%)$. The biggest group of respondents $(50.8 \%)$ was for the respondent from 21 to 23 years old. The second respondents' group is (32.8\%) with age from 18 to 20 years old. While respondents from 24-26 were (14.06\%), and respondents older than 27 were $(2.34 \%)$ which represents the lowest per cent. 


\subsection{Constructs Analysis}

The Smart Partial Least Square-Structure Equation Modeling (PLS-SEM) is the program used to test and analyse the data related to all study hypotheses. Two respective stages of analysis were done. First: investigated the discriminant validity, content, convergent of variables. Moreover, tested each of studly hypotheses related to the study model.

\subsubsection{Path Loading for the Proposed Model}

Figure 2 show five elements (emotional engagement, cognitive engagement, behavioural engagement, and relationship quality and customer loyalty), the reliability of the questionnaires is evaluated by examining their path loadings to find out whether there is, or there is no correlation between the indicators and their latent variables. The generally accepted threshold is the acceptance of indicators with loads (0.55) or more, implying that there is a common variation between variables and their parameters (Falk \& Miller, 1992). The path loading for all factors related to proposed model exceeds the value of $(0.55)$. Therefore, all factors were accepted to analysis (Falk \& Miller, 1992), table 2 shows the Path loading for measures.

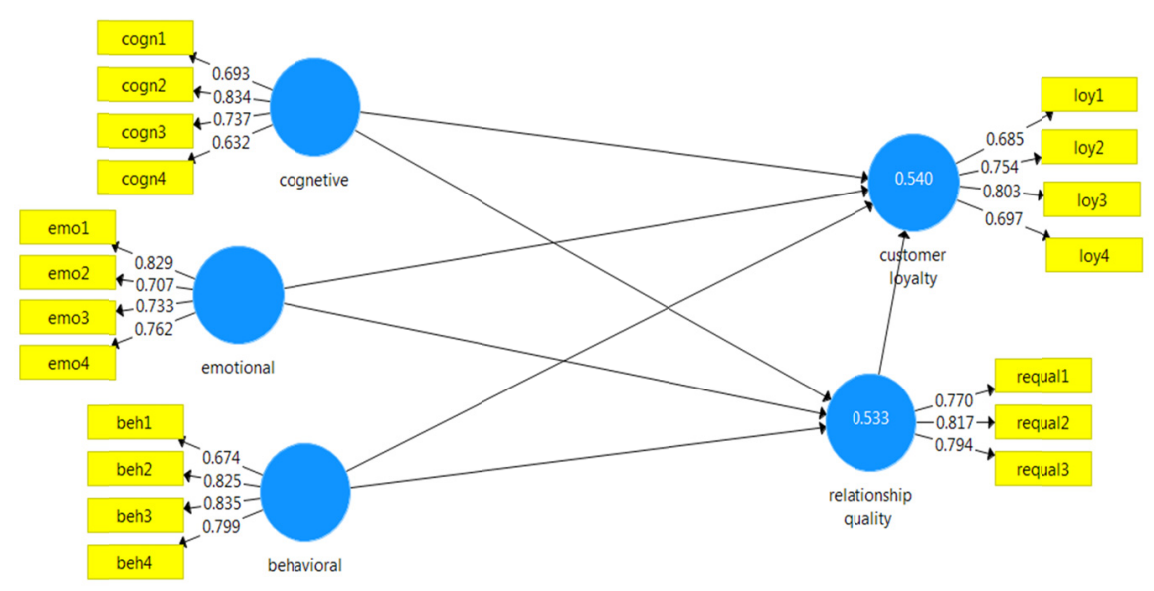

Figure 2. Path loadings for the proposed model

Table 2. Path loading for measures

\begin{tabular}{llll}
\hline Variables & Item & Relationship quality & Result \\
\hline \multirow{4}{*}{ Emotional } & Emo1 & 0.829 & Accepted \\
& Emo2 & 0.707 & Accepted \\
& Emo3 & 0.733 & Accepted \\
& Emo4 & 0.762 & Accepted \\
& Cog1 & 0.693 & Accepted \\
Cognitive & Cog2 & 0.834 & Accepted \\
& Cog3 & 0.737 & Accepted \\
& Cog4 & 0.632 & Accepted \\
Behavioral & Beh1 & 0.674 & Accepted \\
& Beh2 & 0.825 & Accepted \\
& Beh3 & 0.835 & Accepted \\
& Beh4 & 0.799 & Accepted \\
Relationship quality & Requal1 & 0.770 & Accepted \\
& Relqual2 & 0.817 & Accepted \\
& Relaqal3 & 0.794 & Accepted \\
& Loy1 & 0.685 & Accepted \\
& Loy2 & 0.754 & Accepted \\
E-customer loyalty & Loy3 & 0.803 & Accepted \\
& Loy4 & 0.697 & Accepted \\
\hline
\end{tabular}




\subsection{Reliability and Validity Test}

The reliability and validity recognized in any research survey is eventually enhanced by the survey design (Alkhaffaf, Muflih, \& Al-dalahmeh, 2018). Therefore, it is recommended to evaluate the study's accuracy and validity. By ensuring that there are no incorrect responses or lessened to the greatest possible extent, two particular components in the study design need to be taken into account: reliability and validity. To confirm questionnaire predictability, validity and reliability, table 3 have been made to clarify Cronbach alpha (CA), average variance extracted (AVE) and composite reliability (CR) results for all constructs of the proposed model. To ensure internal consistency reliability: Cronbach's alpha was tested all were accepted as they exceed the lowest recommended value of 0.65 (Nunnally \& Bernstein, 1994). Also, AVE value criterion was adopted, as its one of the most important criterion tested regarding convergent validity (Fornell \& Larcker, 1981), all of the AVE values range from $(0.530)$ to $(0.617)$ as seen in the table 3 . All constructs satisfy the convergent validity as they are not less than $(0.50)$; which means that the construct can rationalise more than half of its indicators variance (Fornell \& Larcker, 1981).

Table 3. Validity and reliability results

\begin{tabular}{|c|c|c|c|}
\hline Constructs & Cronbach Alpha (CA) & Composite Reliability (CR) & Average Variance Extracted (AVE) \\
\hline emotional Engagement & 0.759 & 0.844 & 0.576 \\
\hline cognitive Engagement & 0.701 & 0.817 & 0.530 \\
\hline Behavioral Engagement & 0.792 & 0.865 & 0.617 \\
\hline Relationship Quality & 0.706 & 0.836 & 0.630 \\
\hline E-customer loyalty & 0.718 & 0.825 & 0.542 \\
\hline
\end{tabular}

\subsection{Discriminant Validity Test}

The latent variable correlation is calculated, to examine the discriminant validity, which proposes that the construct needs to a higher variance with its measures rather than other constructs (Fornell \& Larcker, 1981). The results of latent variable correlations can be seen in the table 4, which presents all constructs show a higher degree of variance with their indicators when compared to variance with other constructs. Also, discriminant validity considered acceptable because none of the correlation coefficients greater than 1. Therefore, multicollinearity between factors doesn't exist(Hair et al., 2006). After measuring the model testing, with all the parameters tested above, the proposed model can be considered valid and reliable.

Table 4. Discriminant validity

\begin{tabular}{llllll}
\hline & Behavioural & Emotional & Cognitive & $\begin{array}{l}\text { Relationship } \\
\text { Quality }\end{array}$ & E-Customer loyalty \\
\hline Behavioral & 0.786 & & & \\
Emotional & 0.581 & 0.759 & & & \\
Cognitive & 0.520 & 0.631 & 0.728 & & \\
Relationship Quality & 0.611 & 0.580 & 0.646 & 0.794 & 0.736 \\
E-Customer loyalty & 0.516 & 0.532 & 0.622 & 0.692 & \\
\hline
\end{tabular}

\subsection{R2 Test}

In the table 5 below provides an explanation to the values of R2 before and after meditation, path coefficient scheming to provide a clear insight into the link between all constructs along the lines of those mediations construct used. R2 value linked customer engagement factors on e-customer loyalty was found to be 0.455 , without the relationship quality factor, which means it exceeded $25 \%$ which presents a satisfactory and accepted prediction level according to Gaur and Gaur (2006). On the other hand, the value of R2 related to customer engagement with the use of relationship quality as a mediator influence on e-customer loyalty was $(0.540)$, as it exceeds $25 \%$ it is considered accepted prediction value. Expressing accepted prediction level in addition to that R2 value changed from $45.5 \%$ to $54 \%$; this means relationship quality factor increased the percentage of R2 by $8.5 \%$ when applied as mediation factor in the proposed research model under examination. 
Table 5. R2 value

\begin{tabular}{ll}
\hline Relation & $R 2$ \\
\hline The influence of customer engagement factors on e-customer loyalty & 0.455 \\
The influence of customer engagement factors on e-customer loyalty with the mediation of relationship quality & 0.540 \\
\hline
\end{tabular}

\subsection{Hypothesis Testing}

Using bootstrapping analysis in smart PLS software, the researcher provides logical analysis to test the suggested proposed model; to provide a comprehensive conclusion regarding the findings related to the research hypothesis. Through the conduction of bootstrapping test, $(\mathrm{T})$ value for all influences customer engagement factors on ecustomer loyalty, (without the mediation of relationship quality ) has been established .this can be shown in Figure 3.

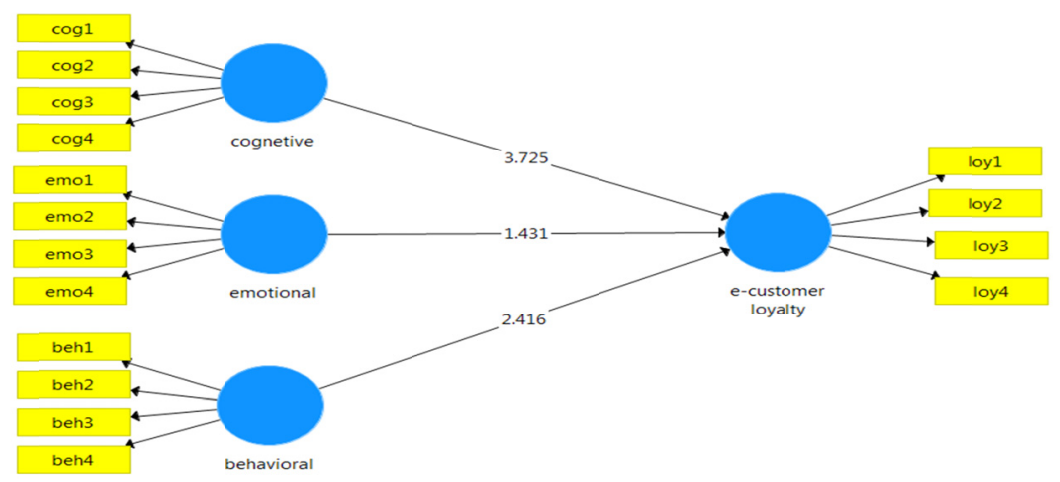

Figure 3. Bootstrapping (T value) for customer engagement factors on e-customer loyalty without the mediation of relationship quality

The $\mathrm{T}$ values can be seen in figure 3, which focused on testing the hypotheses related to the three customer engagements factors; namely emotional, cognitive, and behavioural on e- customer loyalty. Table 6 specifics these results and their values.

Table 6. Test results of customer engagement factors on e-customer loyalty without the mediation of relationship quality

\begin{tabular}{llll}
\hline Relation (direct effect) & P-value $(\alpha)$ & T value & Beta value \\
\hline customer engagement (emotional)on e-loyalty & 0.174 & 1.431 & 0.134 \\
customer engagement (cognitive )on e-loyalty & 0.000 & 3.725 & 0.424 \\
customer engagement (behavioral)on e-loyalty & 0.029 & 2.416 & 0.226 \\
\hline
\end{tabular}

The first part of the study analysis considers the direct influence steaming from customer engagement factors on e-customer loyalty, as outlined in $\mathrm{H} 1$.

Table 6 illustrates H1 which is fragmented into three sub hypotheses: H1.1 There is an influence of cognitive engagement at a significant level $(\alpha \leq 0.05)$ on the e-customer loyalty In Jordanian online environment. Where the statistics $T$ value was found to be (1.362), which provides that H1.1 is not accepted; as $\alpha$ level (0.174) is not accepted and $\mathrm{T}$ value (1.431) is not accepted. Therefore it may be stated that there is no influence of cognitive engagement at a significant level $(\alpha \leq 0.05)$ on the e-customer loyalty In Jordanian online environment.

Additionally, table 6 shows a clarification of H1.2: There is an influence of emotional engagement at a significant level $(\alpha \leq 0.05)$ on the e-customer loyalty In Jordanian online environment, which was accepted. Where the statistic $\mathrm{T}$ value was found to be (3.725), and the Beta value ratio was (0.424), which provides a clear implication as to the alteration of one amount in emotional engagement as reasoning a change equal $(0.424)$ in ecustomer loyalty. So, it may be stated that emotional engagement has a positive influence on e-customer loyalty In Jordanian online environment. 
Furthermore, table 6 illustrates that H1.3: There is an influence of behavioural engagement at a significant level $(\alpha \leq 0.05)$ on the e-customer loyalty In Jordanian online environment was accepted. Where the statistic $\mathrm{T}$ value was found to be $(2.416)$, and the Beta value ratio was $(0.226)$, which provides a clear implication as to the alteration of one amount in emotional engagement as reasoning a change equal $(0.226)$ in e- customer loyalty. So, it may be stated that behavioural engagement has a positive influence on e-customer loyalty In Jordanian online environment.

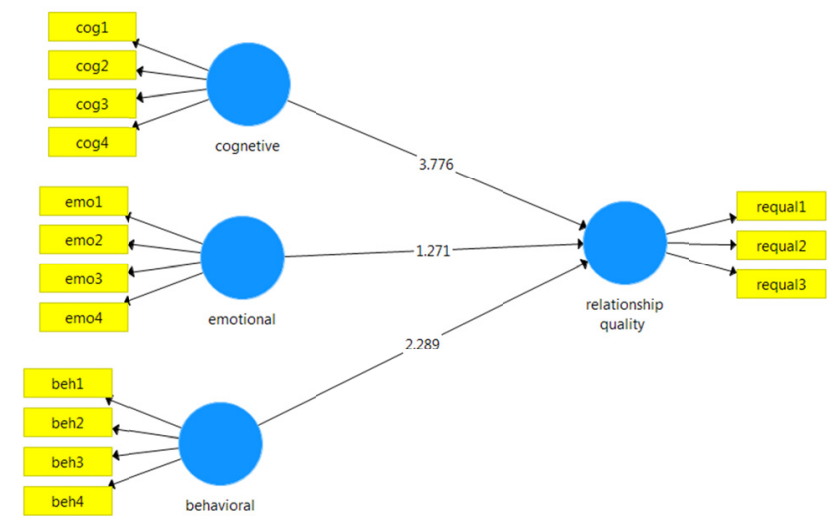

Figure 4. Bootstrapping ( $\mathrm{T}$ value) for customer engagement factors on relationship quality

Table 7. Test results of customer engagement factors on relationship quality

\begin{tabular}{llll}
\hline Relation (direct effect) & $P$-value $(\alpha)$ & T value & Beta value \\
\hline customer engagement (emotional)on relationship quality & 0.2080 & 1.271 & 0.160 \\
customer engagement (cognitive )on relationship quality & 0.0001 & 3.776 & 0.379 \\
customer engagement (behavioral)on relationship quality & 0.0156 & 2.289 & 0.330 \\
\hline
\end{tabular}

The second part of the study analysis considers the direct influence steaming from customer engagement factors on relationship quality, as outlined in $\mathrm{H} 2$.

The $\mathrm{T}$ values can be seen in figure 4, which focused on testing the hypotheses related to the three customer engagements factors; namely emotional, cognitive, and behavioural on relationship quality.

Table 7 illustrates that $\mathrm{H} 2.1$ there is an influence of emotional engagement at a significant level $(\alpha \leq 0.05)$ on the relationship quality. In Jordanian online environment was rejected. Where the statistics $\mathrm{T}$ value was found to be (1.271), which provides that H1.1 is not accepted; as $\alpha$ level was $(0.2080)$ is not accepted and T value is not accepted, therefore it may be stated that there is no influence of emotional engagement at a significant level $(\alpha \leq 0.05)$ on the relationship quality In Jordanian online environment.

Table 7 clarifies that H2.2: there is an influence of cognitive engagement at a significant level $(\alpha \leq 0.05)$ on the relationship quality In Jordanian online environment was accepted. Where the statistic $\mathrm{T}$ value was found to be (3.776), and the Beta value ratio was (0.379), which provides a clear implication as to the alteration of one amount in cognitive engagement as reasoning a change equal (0.379) in e- customer loyalty. Therefore, it may be specified that cognitive engagement has a positive influence on relationship quality In Jordanian online environment.

Table 7 illustrates that H2.3: there is an influence of behavioural engagement at a significant level $(\alpha \leq 0.05)$ on the relationship quality. In Jordanian online environment was accepted. Where the statistic T value was found to be (2.289), and the Beta value ratio was (0.330), which provides a clear implication as to the alteration of one amount in behavioural engagement as reasoning a change equal (0.330) in e- customer loyalty. Accordingly, it may be specified that behavioural engagement has a positive influence on relationship quality In Jordanian online environment. 


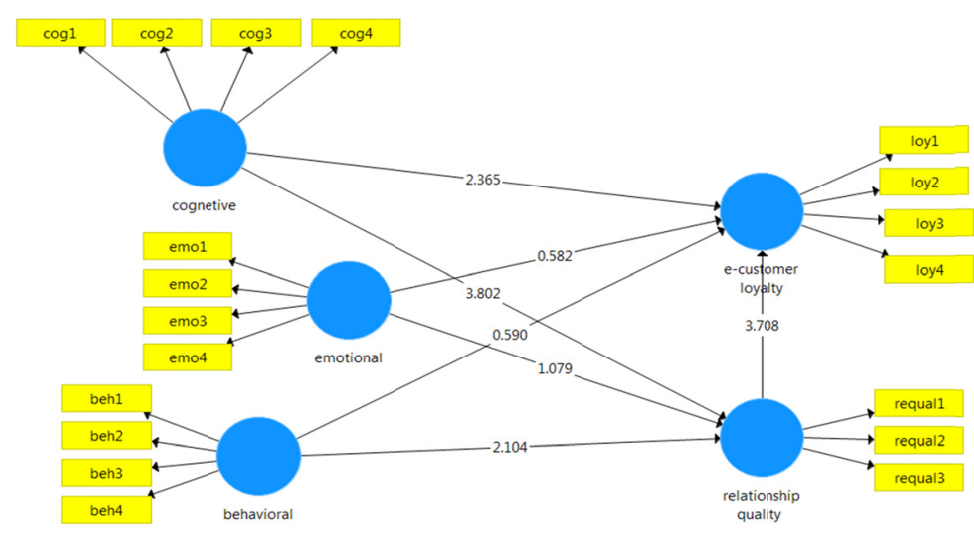

Figure 5. Bootstrapping (T value) for relationship quality on e-customer loyalty

Table 8. Test results of relationship quality on e-customer loyalty

\begin{tabular}{llll}
\hline Relation (direct effect) & $P$-value $(\alpha)$ & T value & Beta value \\
\hline relationship quality on e- customer loyalty & 0.000 & 3.489 & 0.443 \\
\hline
\end{tabular}

The third part of the study analysis considers the direct influence steaming from relationship quality on e-customer loyalty, as outlined in $\mathrm{H} 3$.

Table 8 illustrates that H3: there is an influence of relationship quality at a significant level $(\alpha \leq 0.05)$ on ecustomer loyalty In Jordanian online environment was accepted. Where the statistic $\mathrm{T}$ value was found to be (3.708), and the Beta value ratio was (0.443), which provides a clear implication as to the alteration of one amount in relationship quality as reasoning a change equal (0.443) in e- customer loyalty. Accordingly, it may be specified relationship quality has a positive influence on e- customer loyalty In Jordanian online environment.

The fourth part of the study analysis considers the indirect influences between customer engagements factors mediated through relationship quality on customer loyalty. Therefore, $\mathrm{T}$ values can be seen in figure 5 .

Further, researcher established the (T) values through adoption of Smart Partial Least Square (PLS-SEM), which examined the indirect effect of customer engagement on e-customer loyalty mediating by' relationship quality, as shown in table 9. H4.1: The relationship quality has mediated the relation of emotional engagement and ecustomer loyalty in Jordanian online environment $(\alpha \leq 0.05)$ was rejected. Where the statistics $T$ value was found to be (0.91640), which provides that H4.1 is not accepted; as $\alpha$ level was $(0.1635)$ is not accepted and T value is not accepted, therefore it may be stated that relationship quality doesn't mediate the relation of emotional engagement and e- customer loyalty in Jordanian online environment $(\alpha \leq 0.05)$.

Table 9 illustrates H4.2: The relationship quality has mediated the relation of cognitive engagement and ecustomer loyalty in Jordanian online environment $(\alpha \leq 0.05)$ was accepted. Where the statistic T value was found to be (2.6297), and the Beta value ratio was (0.1693). Accordingly, it may be specified that relationship quality partially mediates the relation of cognitive engagement and e- customer loyalty in Jordanian online environment $(\alpha \leq 0.05)$.

Table 9 shows that H4.3: The relationship quality has mediated the relation of behavioural engagement and ecustomer loyalty in Jordanian online environment $(\alpha \leq 0.05)$ was accepted. Where the statistic T value was found to be (1.7963), and the Beta value ratio was $(0.1442)$. Accordingly, it may be specified that relationship quality partially mediates the relation of behavioural engagement and e- customer loyalty in Jordanian online environment $(\alpha \leq 0.05)$. 
Table 9. Test results of customer engagement factors on e- customer loyalty mediating by relationship quality

\begin{tabular}{llll}
\hline Relation (indirect effect) & P-value $(\alpha)$ & T value & Beta value \\
\hline customer engagement (emotional) $>$ relationship quality $>$ e-customer loyalty & 0.1635 & 0.91640 & 0.0661 \\
customer engagement (cognitive ) ) > relationship quality > e-customer loyalty & 0.0040 & 2.6297 & 0.1693 \\
customer engagement (behavioral) ) > relationship quality > e-customer loyalty & 0.0347 & 1.7963 & 0.1442 \\
\hline
\end{tabular}

Summaries of research hypotheses result can be seen in the table 10 .

Table 10. Summary of hypotheses results

\begin{tabular}{ll}
\hline Research hypotheses & Result \\
\hline H1.1 & Rejected \\
H1.2 & accepted \\
H1.3 & accepted \\
H2.1 & Accepted \\
H2.2 & Accepted \\
H2.3 & Rejected \\
H3 & Accepted \\
H4.1 & Rejected \\
H4.2 & Accepted \\
H4.3 & Accepted \\
\hline
\end{tabular}

\section{Discussion, Implications and Conclusions}

In this study, we aimed to find out how customer engagement influences e-customer loyalty in the context of the online environment.

The customer engagement factor has been empirically investigated in limited Studies. And it's been mostly measured on physical goods (Sprott et al., 2009; Vivek et al., 2014); Calder et al., (2009); Hollebeek et al. (2014) investigated customer engagement in social media and online websites; meanwhile, studies on customer engagement used qualitative research method (Brodie et al., 2013; Hollebeek, 2011), this study used a quantitative approach to empirically investigate the proposed conceptual model.

In this study, investigating the influence of customer engagement on e-customer loyalty and relationship quality is an important and significant finding. The influential results confirmed that customer (cognitive) engagement has the most significant effect on e-customer loyalty, compared to the other variables.

The findings in this study also make a contribution to the existing literature on online environments, particularly, and in the marketing area in general. The model in this current research clarifies the interrelationships among important marketing constructs in the online environment: customer emotional engagement, customer cognitive engagement, customer behavioural engagement, relationship quality, and e-customer loyalty, using a hierarchical model as the framework. This current study not only empirically examines the direct relationships but also the mediating relations among the selected constructs.

As relationship quality has been proven as an important construct affecting e-customer loyalty, there is an important need to understand whether other variables have a positive Influence on e-customer loyalty. Based on the SEM analysis, relationship quality is an important factor affecting e-customer loyalty. The relationship between relationship quality factor and e-customer loyalty is positive and significant (Beta $=0.443, \mathrm{~T}=3.778$ ), illustrating that good relationship with customers is leading to high e-loyalty of online interactive customers this result is supported by Hennig-Thurau et al. (2002).

This current research not only found a direct relationship between customer engagements and e-customer loyalty. But it examined the mediating role of relationship quality. An interesting finding in this current study is the mediating effect of relationship quality on the relationship between customer engagements and e- customer loyalty was partially mediation which supports the result of (Hollebeek, 2011a) and Nammir et al. (2012). Moreover, No fully mediation is proven. Meanwhile, customer engagements have a direct impact on e-customer loyalty, this result support by (Brodie et al., 2013; Van Doorn et al., 2010), relationship quality also has a direct impact on e-customer loyalty (Hennig-Thurau et al., 2002). As well as customer engagements have a positive impact in term of (cognitive and behavioural engagements) on relationship quality. 
From a managerial perspective, measuring customer engagement's impact on e-customer Loyalty reflects psychological manners and clarifies the relation between customers, and online interactive environment. The connection drives favourable behavioural intentions and encourages interaction within the online environment. The high technology available and Communications also encourages customers to show their behavioural and cognitive traits of engagement, which helps organisations to find out encouraging behavioural intentions to satisfy customers and reach their loyalty in the online environments.

The importance of social media interaction is becoming important as its being an important channel for companies to engage and interact with customers.

A lot of mangers chose careful strategy within the use of social media, mostly; they use tactics of trial and error in while engaging with customers via social media; which doesn't seem effective (Pongpaew et al., 2011). Research on this area will help organisations to choose strategies regarding engaging with customers online and using social media, focusing on the relationship with customers to achieve e-customer loyalty.

To sum up, this paper focused on developing more in-depth insight into the direct and indirect relationships between customer engagement factors and e-customer loyalty. First, relationship quality significantly mediates the relationship between customer engagement and e-customer loyalty. As it mediates the relation between cognitive and behavioural engagement, and e-customer loyalty relations. Second, both cognitive and behavioural engagement show significant impact on e-customer loyalty. Third, relationship quality has a significant impact on e-customer loyalty .finally; emotional engagement have no impact on e-customer loyalty, neither on the relation with relationship quality, which means no partial or full mediation occurred.

\section{Limitations and Direction for Future Research}

The results of this study are created on a convenience sample of online interactive Facebook users in Jordan. Future studies are suggested to incorporate other social networking platforms like Instagram and twitter etc. to come up with more diverse understanding and results. Moreover, there is a need for Future research by establishing other components that could adopt a mediatory role in enhancing relationships between customer engagement and e-customer loyalty especially emotional engagement. Future research may reuse the conceptual research model used in this study and apply it to forecast e-customer loyalty in service and product industries, and in other countries with different cultures, to enhance the understanding of the factors affecting customer loyalty.

\section{References}

Alkhaffaf, M., Muflih, M., \& Al-Dalahmeh, M. A. H. M. O. U. D. (2018). An Integrated Model of Knowledge Management Enablers and Organizational Creativity: The Mediating Role of Knowledge Management Processes in Social Security Corporation in Jordan. Journal of Theoretical and Applied Information Technology, 96(3).

Bagozzi, R. P., \& Dholakia, U. M. (2006). Antecedents and purchase consequences of customer participation in small group brand communities. International Journal of Research in Marketing, 23(1), 45-61. https://doi.org/10.1016/j.jiresmar.2006.01.005

Bagozzi, R. P., \& Yi, Y. (2012). Specification, Evaluation, and Interpretation of Structural Equation Models. Journal of the Academy of Marketing Science, 40(1), 8-34. https://doi.org/10.1016/j.ijresmar.2006.01.005

Balaji, M. S. (2015). Investing in customer loyalty: the moderating role of relational characteristics. Serv. Bus., 9(1), 17-40. https://doi.org/10.1007/s11628-013-0213-y

Baldus, B. J., Voorhees, C., \& Calantone, R. (2015). Online brand community engagement: Scale development and validation. Journal of Business Research, 68(5), 978-985. https://doi.org/10.1016/j.jbusres.2014.09.035

Bejou, D., Wray, B., \& Ingram, T. N. (1996). Determinants of relationship quality: and artificial neural network analysis. Journal of Business Research, 36, 137-143.

Bowden, J. L. H. (2009). The process of customer engagement: a conceptual framework. The Journal of Marketing Theory and Practice, 17(1), 63-74. https://doi.org/10.2753/MTP1069-6679170105

Bowden, J. L., Gabbott, M., \& Naumann, K. (2014). Service relationships and thecustomer disengagement engagement conundrum. Journal of Marketing Management, 31(7/8), 774-806. https://doi.org/10.1080/0267257X.2014.983143

Brodie, R. J., Ilic, A., Juric, B., \& Hollebeek, L. (2013). Consumer engagement in a virtual brand community: an exploratory analysis. Journal of Business Research, 66(1), 105-114. 
https://doi.org/10.1016/j.jbusres.2011.07.029

Burbary, K. (2011). Facebook demographics revisited-2011 Statistics. Retrieved from http://socialmediatoday.com/kenburbary/276356/facebook-demographicsrevisited-2011-statistics

Calder, B. J., Malthouse, E. C., \& Schaedel, U. (2009). An experimental study of the relationship between online engagement and advertising effectiveness. Journal of Interactive Marketing, 23(4), 321-331. https://doi.org/10.1016/j.intmar.2009.07.002

Carlson, J., \& O'Cass, A. (2010). Exploring the relationships between e-service quality, satisfaction, attitudes and behaviours in content-driven e-service web sites. Journal of services marketing, 24(2), 112-127. https://doi.org/10.1108/08876041011031091

Chandler, J. D., \& Lusch, R. F. (2015). Service systems: a broadened framework and research agenda on value propositions, engagement, and service experience. Journal of Service Research, 18(1), 6-22. https://doi.org/10.1177/1094670514537709

Crosby, L. A., Evans, K. R., \& Cowles, D. (1990). Relationship quality in servicesselling: An interpersonal influence perspective. Journal of Marketing, 54(3), 68-81. https://doi.org/ 10.1177/002224299005400306

De Wulf, K., \& Odekerken-Schro"der, G. (2001). A critical review of theories underlying relationship marketing in the context of explaining consumer relationships. Journal for the Theory of Social Behaviour, 31(1), 73-102. https://doi.org/10.1111/1468-5914.00147

Dessart, L., Veloutsou, C., \& Morgan-Thomas, A. (2015). Consumer engagement in online brand communities: A social media perspective. Journal of Product \& Brand Management, 24(1), 28-42. https://doi.org/10.1108/JPBM-06-2014-0635

Dick, A. S., \& Basu, K. (1994). Customer loyalty: toward an integrated conceptual framework. Journal of the Academy of Marketing Science, 22(2), 99-113. https://doi.org/ 10.1177/0092070394222001

Fabrigar, L. R., Porter, R. D., \& Norris, M. E. (2010). Some Things You Should Know about Structural Equation Modeling but Never Thought to Ask. Journal of Consumer Psychology, 20(2), 221-25. https://doi.org/10.1016/j.jcps.2010.03.003

Falk, R. F., \& Miller, N. B. (1992). A primer for soft modeling: for measuring customer engagement. Journal of Marketing Theory and Practice, 22(4), 401-420.

Fornell, C. (1992). A National customer satisfaction barometer: The Swedish experience. Journal of Marketing, 55, 1-21. https://doi.org/10.1177/002224299205600103

Garbarino, E., \& Johnson, M. S. (1999). The Different Roles of Satisfaction, Trust, and Commitment in Customer Relationships. Journal of Marketing, 63(2), 70-87. https://doi.org/10.1177/002224299906300205

Gaur, A. S., \& Gaur, S. S. G. (2006). Statistical Methods for Practice and Research. New Delhi: Sage Publication. https://doi.org/10.5555/1695801

Gil, I., Berenguer, G., \& Cervera, A. (2008). The roles of service encounters, service value and job satisfaction in achieving customer satisfaction in business relationships. Industrial Marketing Management, 37, 921-939. https://doi.org/10.1016/j.indmarman.2007.06.008

Gruen, T. W., Summers, J. O., \& Acito, F. (2000). Relationship marketing activities, commitment, and membership behaviors in professional associations. Journal of Marketing, 64(3), 34-49. https://doi.org/10.1509/jmkg.64.3.34.18030

Gummerus, J., Liljander, V., Weman, E., \& Pihlström, M. (2012). Customer engagement in a Facebook brand community. Management Research Review, 35(9), 857-877. https://doi.org/10.1108/01409171211256578

Guo, L., Zhang, M., \& Wang, Y. (2016). Influences of customers' psychological characteristics on 28 their engagement behavior in company social networks. Social Behavior and Personality, 44(10), 1661-1670.

Hair, W., Black, R., Anderson, B. R., Babin, R. L. (2006). Tahtam Multivariate Data Analysis with Readings Mcmillan Book Company.

Hennig-Thurau, T., Gwinner, K. P., \& Gremler, D. D. (2002). Understanding relationship marketing outcomes: an integration of relational benefits and relationship quality. Journal of Service Research, 4(3), 230-247. https://oi.org/10.1177/1094670502004003006

Hennig-Thurau, T., Gwinner, K., \& Gremler, D. (2002). Understanding relationship marketing outcomes: an integration of relationship benefits and relationship quality. Journal of Service Research, 4(3), 230-47. 
https://doi.org/10.1177/1094670502004003006

Hollebeek, L. D. (2011a). Demystifying customer brand engagement: Exploring the loyalty nexus. Journal of Marketing Management, 27(7/8), 785-807. https://doi.org/10.1080/0267257X.2010.500132

Hollebeek, L. (2011b). Exploring customer brand engagement: definition and themes. Journal of Strategic Marketing, 19(7), 555-573. https://doi.org/10.1080/0965254X.2011.599493

Hollebeek, L. D., Conduit, J., \& Brodie, R. J. (2016). Strategic drivers, anticipated and unanticipated outcomes of customer engagement. https://doi.org/10.1080/0267257X.2016.1144360

Hollebeek, L. D., Glynn, M. S., \& Brodie, R. J. (2014). Consumer brand engagement in social media: conceptualization, scale development and validation. Journal of Interactive Marketing, 28(2), 149-165. https://doi.org/10.1016/j.intmar.2013.12.002

Hollebeek, L., \& Chen, T. (2014). Exploring positively-versus negatively-valenced brand engagement: A conceptual model. Journal of Product and Brand Management, 23(1), 62-74. https://doi.org/10.1108/JPBM-06-2013-0332

Hur, Y. J., Ko, Y. J., \& Valacich, J. (2011). A Structural Model of the Relationships between Sport Website Quality, E-Satisfaction, and E-Loyalty. Journal of Sport Management, 25, 458-473. https://doi.org/10.1123/jsm.25.5.458

Husnain, M., \& Akhtar, W. (2016). Relationship Marketing and Customer Loyalty: Evidence from Banking Sector in Pakistan. Global Journal of Management and Business Research: E Marketing, 15(10), 1.

Islam, J. U., \& Rahman, Z. (2017). The impact of online brand community characteristics on customer engagement: An application of Stimulus-Organism-Response paradigm. Telematics and Informatics, 34(4), 96-109. https://doi.org/10.1016/j.tele.2017.01.004

Islam, J., \& Rahman, Z. (2016). Linking customer engagement to trust and word of mouth on Facebook brand communities: an empirical study. J. Internet Commerce, 15(1), 40-58. https://doi.org/10.1080/15332861.2015.1124008

Kontu, H., \& Vecchi, A. (2014). Why all that noise - assessing the strategic value of social media for fashion brands. Journal of Global Fashion Marketing, 5(3), 235-250. https://doi.org/10.1080/20932685.2014.912443

Kosiba, J. P. B., Boateng, H., Okoe Amartey, A. F., Boakye, R. O., \& Hinson, R. (2018). Examining customer engagement and brand loyalty in retail banking: The trustworthiness influence. International Journal of Retail \& Distribution Management, 46(8), 764-779. https://doi.org/10.1108/IJRDM-08-2017-0163

Kosiba, J. P. B., Boateng, H., Okoe Amartey, A. F., Boakye, R. O., \& Hinson, R. (2018). Examining customer engagement and brand loyalty in retail banking: The trustworthiness influence. International Journal of Retail \& Distribution Management, 46(8), 764-779.https://doi.org/10.1108/IJRDM-08-2017-0163

Kotler, P., \& Kevin, L. K. (2016). Marketing Management (15th ed.). New Jersey: Pearson Pretice Hall, Inc.

Krystallis, A., Chrysochou, P. (2014). The influences of service brand dimensions on brand loyalty. J. Retail. Consum. Serv., 21(2), 139-147. https://doi.org/10.1016/j.jretconser.2013.07.009

Kumar, V., Aksoy, L., Donkers, B., Venkatesan, R., Wiesel, T., \& Tillmanns, S. (2010). Undervalued or overvalued customers: capturing total customer engagement value. Journal of service research, 13(3), 297-310. https://doi.org/10.1177/1094670510375602

Lewin, J. (2009). Business customers' satisfaction: What happens when supplier downsize? Industrial Marketing Management, 38, 283-299. https://doi.org/10.1016/j.indmarman.2007.11.005

Liu, C. T., Guo, Y. M., \& Lee, C. H. (2011). The influences of relationship quality and switching barriers on customer loyalty. International Journal of Information Management, 31(1), 71-79. https://doi.org/10.1016/j.ijinfomgt.2010.05.008

Marzocchi, G., Morandin, G., \& Bergami, M. (2013). Brand communities: loyal to the community or the brand. European Journal of Marketing, 47(1/2), 93-114. https://doi.org/10.1108/03090561311285475

Mollen, A., \& Wilson, H. (2010). Engagement, telepresence and interactivity in onlineconsumer experience: reconciling scholastic and managerial perspectives. Journal of Business Research, 63(9), 919-925. https://doi.org/doi.org/10.1016/j.jbusres.2009.05.014

Moorman, C., Gerald, Z., \& Rohid, D. (1992). Relationships between Providers and Users of Market Research: The Dynamics of Trust within and between Organizations. Journal of Marketing Research, 29(August), 
314-28. https://doi.org/10.1177/002224379202900303

Morgan, R. M., \& Hunt, S. D. (1994). The commitment-trust theory of relationship marketing. Journal of marketing, 58(3), 20-38. https://doi.org/10.1177/002224299405800302

Nammir, D. S. S., Marane, B. M., \& Ali, A. M. (2012). Determine the role of customer engagement on relationship quality and relationship performance. European Journal of Business and Management, 4(11), 27-36.

Nunnally, J. C., \& Bernstein, I. H. (1994). Psychometric theory (3rd ed.). New York, NY: McGraw-Hill, Inc. https://doi.org/10.1177/073428299901700307

Patterson, A. (2012). Social-networkers of the world, unite and take over: A meta-introspective perspective on the Facebook brand. Journal of Business Research, 65(4), 527-534. https://doi.org/10.1016/j.jbusres.2011.02.032

Patterson, P., Yu, T., \& De Ruyter, K. (2006). Understanding customer engagement in services. In Advancing theory, maintaining relevance, proceedings of ANZMAC 2006 conference, Brisbane (pp. 4-6).

Pongpaew, W., Speece, M., \& Tiangsoongnern, L. (2017). Social presence and customer brand engagement on Facebook brand pages. Journal of Product \& Brand Management, 26(3), 262-281. https://doi.org/10.1108/JPBM-08-2015-0956

Pritchard, M. P., Mark, E. H., \& Dennis, R. H. (1999). Analyzingthe Commitment-Loyalty Link in Service Contexts. Journal of the Academy of Marketing Science, 27, 333-48. https://doi.org/10.1177/0092070399273004

Puriwat, W., \& Tripopsakul, S. (2014). The investigation of the influence of service quality toward customer engagement in service dominant industries in Thailand. International Proceedings of Economics Development and Research, 82, 42. https://doi.org/10.7763

Reichheld, F. F., Markey, Jr, R. G., \& Hopton, C. (2000). E-customer loyalty-applying the traditional rules of business for online success. European Business Journal, 12(4), 173.

Rissanen, H., \& Luoma-Aho, V. (2016). (Un)willing to engage? First look at the engagement types of millennials. An International Journal, 21(4), 500-515. https://doi.org/10.1108/CCIJ-06-2015-0038

Roblyer, M. D., McDaniel, M., Webb, M., Herman, J., \& Witty, J. V. (2010). Findings on Facebook in higher education: a comparison of college faculty and student uses and perceptions of social networking sites. Internet Higher Educ., 13(3), 134-140. https://doi.org/10.1016/j.iheduc.2010.03.002

Smith, J. B. (1998). Buyer-seller relationships: similarity, relationship management, and quality. Psychology \& Marketing, 15(1), 3-21. https://doi.org/10.1002

So, K. K. F., King, C., Sparks, B. A., \& Wang, Y. (2016a). The role of customer engagement in building consumer loyalty to tourism brands. Journal of Travel Research, 55(1), 64-78. https://doi.org/10.1177/0047287514541008

So, K. K. F., King, C., Sparks, B. A., \& Wang, Y. (2016 b). Enhancing customer relationships with retail service brands: The role of customer engagement. Journal of Service Management, 27(2), 170-193. https://doi.org/10.1108/JOSM-05-2015-0176

Sprott, D., Czellar, S., \& Spangenberg, E. (2009). The importance of a general measure of brand engagement on market behavior: development and validation of a scale. Journal of Marketing Research, 46(1), 92-104. https://doi.org/10.1509/jmkr.46.1.92

Srinivasan, S., Anderson, R., \& Ponnavolu, K. (2002). Customer loyalty in e-commerce: An exploration of its antecedents and consequences. Journal of Retailing, 78(1), 41-50. https://doi.org/10.1016/S0022-4359(01)00065-3

Tsai, H. T., \& Pai, P. (2014). Why do newcomers participate in virtual communities? An integration of self-determination and relationship management theories. Decision Support Systems, 57, 178-187. https://doi.org/10.1016/j.dss.2013.09.001

Van Doorn, J., Lemon, K. N., Mittal, V., Nass, S., Pick, D., Pirner, P., \& Verhoef, P. C. (2010). Customer engagement behavior: theoretical foundations and research directions. Journal of Service Research, 13(3), 253-266. https://doi.org/10.1177/1094670510375599

Vargo, S. L., \& Lusch, R. F. (2004). Evolving to a new dominant logic for marketing. Journal of Marketing, 
68(1), 1-17.

Vivek, S. D., Beatty, S. E., \& Morgan, R. M. (2012). Customer engagement: Exploring customer relationships beyond purchase. The Journal of Marketing Theory and Practice, 20(2), 122-146. https://doi.org/10.2753/MTP1069-6679200201

Vivek, S. D., Beatty, S. E., \& Morgan, R. M. (2012). Customer engagement: Exploring customer relationships beyond purchase. The Journal of Marketing Theory and Practice, 20(2), 122-146. https://doi.org/10.2753/MTP1069-6679200201

Vivek, S. D., Beatty, S. E., Dalela, V., \& Morgan, R. M. (2014). A generalized scale for measuring customer engagement. Journal of Marketing Theory and Practice, 22(4), 401-420. https://doi.org/10.2753/MTP1069-6679220404

Wagner, C., \& Majchrzak, A. (2006). Enabling customer-centricity using wikis and the wiki way. Journal of Management Information Systems, 23(3), 17-43. https://doi.org/10.2753/MIS0742-1222230302

Wray, B., Palmer, A., \& Bejou, D. (1994). Using neural network analysis to evaluatebuyer-seller relationships. European Journal of Marketing, 28, 32-48. https://doi.org/10.1108/03090569410075777

\section{Copyrights}

Copyright for this article is retained by the author(s), with first publication rights granted to the journal.

This is an open-access article distributed under the terms and conditions of the Creative Commons Attribution license (http://creativecommons.org/licenses/by/4.0/). 